\title{
Self-Medication with Painkillers in the Municipality of Bačka Topola
}

\author{
Tinde I. Halgato ${ }^{1}$, Ana D. Tomas ${ }^{2}$, Milica M. Paut Kusturica ${ }^{2}$, \\ Olga J. Horvat ${ }^{2}$ \\ ${ }^{1}$ Health Center “ Dr Janoš Hadži” Bačka Topola, Serbia \\ ${ }^{2}$ Department of Pharmacology, Toxicology and Clinical Pharmacology, Faculty of Medicine \\ Novi Sad, University of Novi Sad, Novi Sad, Serbia
}

\section{SUMMARY}

Introduction: In Serbia, analgesics are available without a doctor's prescription and using painkillers without previous consultation with a family physician has been ever more common among patients.

Aim: The aim of this study was to investigate the attitudes about self-medication for pain relief and and characteristics of self-medication among patients in the municipality of Bačka Topola.

Subjects and Methods: The study was conducted betweeen September 20, 2017 and September 29, 2017 in three General practice medical centres of the municipality of Bačka Topola. 136 adult patients, who agreed to fill in an anonymous questionnaire participated in the survey.

Results: $75 \%$ of the study subjects used painkillers during the last year. The most common indications were headache $52 \%$, joint pain $33 \%$ and back pain. $41 \%$ of the subjects said they used painkillers once a month. The most commonly used pain reliever was ibuprofen $47 \%$ followed by diclofenac $28 \%$ and aspirin $21 \%$. $48 \%$ of our subjects did not seek advice from their family physician (self-medication) because the pain was not too strong and did not not last too long. while $32 \%$ of the subjects referred to earlier experience. $77 \%$ of subjects said they knew side effects of analgesics, but only $40 \%$ of them named it. $42 \%$ of subjects did not contact a family physician due to mild pain, $29 \%$ because of saving the time. $77 \%$ of subjects said that they are familiar with the side effects of analgesics, but only $40 \%$ could name them.

Conclusions: The results of our study point out that the patients' knowledge about painkillers plays a very important role in their rational consumption. Therefore, educational campaigns about the behaviour of patients towards painkillers are the key elements to ensure quality and knowledge based use of these drugs among patients.

Keywords: nonsteroidal anti-inflammatory drugs, adverse reactions, irrational use of medicines 


\section{INTRODUCTION}

Pain is one of the most common medical symptoms and non-steroidal anti-inflammatory drugs (NSAIDs) are among the most commonly used medications [1]. The objective of pain elimination is to enable normal functioning of the patients in working and daily activities. Painkillers are the most effective way to eliminate and relieve pain. Pain, which is an unconfortable feeling, may occur suddenly and for that reason we usually need to eliminate it quickly. In most cases we decide to take painkillers for pain relief without consulting a physician or pharmacist about the type of analgesic and its side effects. There are numerous reasons for self-medication [2]. Self-medication has many advantages - we can save time by avoiding making appointments and waiting for examinations at the doctor's office, we can avoid paying for examination and last but not least the pharmacies are more available than doctors. NSAIDs are the most commonly used painkillers [3]. In SerbiaNSAIDs can be purchased without a prescription, and are widely used because of their anti-inflammatory, analgesic and antipyretic effects. However, nephrotoxicity remains a major concern with these drugs; other systems such as gastrointestinal, cardiovascular, hematologic, respiratory, and hepatic are also affected [4]. Responsibility remains with all healthcare professionals to establish the balance between the benefits and risks associated with these drugs. The patients who uses the drugs and the policy-framing bodies are others who could intervene in promoting the rational use of NSAIDs $[5,6]$.

\section{AIM}

According to the above mentioned data, the aim of this study was to assess the attitudes about self-medication for pain relief and and characteristics of self-medication among patients in the municipality of Bačka Topola.

\section{SUBJECTS AND METHODS}

The study was conducted in Bačka Topola municipality (which includes 23 local communities), with 33.321 inhabitants (according to the 2011 Census). The study sample included adult subjects who consulted general practitioners at any of three general practice medical centers in Bačka Topola (in local communities
Bačka Topola, Bajsa and Panonija) between September 20, 2017 and September 29, 2017. and agreed to participate in the study. After giving their written informed consent, they were instructed by the researchers on how to complete the questionnaire. Patients who visited these clinics several times filled in the questionnaire only once. The study was approved by the Ethics Committee of the Faculty of Medicine in Novi Sad (approval number 01-39/64/1) and the Ethics Committee of the Health Center „Dr Hadži Janoš” in Bačka Topola (approval number 01-2051-2).

The total number of questionnaires which were distributed among the patients in the three health centers of the above mentioned institute was 160 . The questionnaire used in the research was based on the questionnaire by Brlić and his colleagues which had been used in the earlier study [7].

The content, comprehensibility, readability and appearance of the questionnaire were previously tested on 30 adult subjects in Bačka Topola. According to the test samples we made some necessary changes in the questionnaires.

The subjects needed five or at least ten minutes to complete the questionnaire.

The questionnaire consisted of three separate parts. Firstly, it contained questions providing information about the patients' socio-demographic characteristics. Secondly, our goal was to collect data about: the leading health problems for which painkillers were used, which drugs were most commonly used and how frequently, the level of patients' knowledge about drug side effects, the intensity of pain for which analgesics is used and whether they read drug package inserts at all. Finally, we would also have found out whether the patients use alternative methods for pain relief.

The collected data from the questionnaires was statistically processed in Microsoft Excel 2007.

\section{RESULTS}

Out of 160 patients who received the questionnaire, 136 patients completed the entire questionnaire. The average age of patients was $50.06 \pm 16.56$ years.

$75 \%$ of the patients reported taking 
Table 1. Using analgesics in the past year

Table 2. Subjective assessment of pain intensity

1 (mild pain) - 7 (very severe pain)

Table 3. The subjects' answers to the question:How long does the pain last before contacting a doctor?

Table 4. The subjects' answers to the question: How often do you use a painkiller?

\begin{tabular}{|l|c|c|c|c|}
\hline Have you used an analgesic last year? & $n$ & $\%$ & Female & Male \\
\hline Yes & 110 & 80.8 & $75(85 \%)$ & $35(73 \%)$ \\
\hline No & 26 & 19.1 & $13(15 \%)$ & $13(27 \%)$ \\
\hline
\end{tabular}

analgesics during the last year. $85 \%$ of female and $73 \%$ of male subjects took medication to pain relief (Table 1.).

The study subjects were asked to assess the intensity of pain subjectively on a 1-7 scale according to the limit when they need to takea painkiller (Table 2.). On the scale $1 \mathrm{de}$ notes the mild pain and 7 a very severe pain.

\begin{tabular}{|l|c|c|c|c|c|c|c|}
\hline & 1 & 2 & 3 & 4 & 5 & 6 & 7 \\
\hline $\mathrm{n}$ & 4 & 3 & 13 & 22 & 20 & 17 & 55 \\
\hline$\%$ & 2.9 & 2.2 & 9.7 & 16.4 & 14.9 & 12.6 & 41 \\
\hline & 1 & 2 & 3 & 4 & 5 & 6 & 7 \\
\hline Female & $1(1.1 \%)$ & $1(1.1 \%)$ & $7(7.9 \%)$ & $12(13.6 \%)$ & $14(15.9 \%)$ & $10(11.3 \%)$ & $42(47.7 \%)$ \\
\hline Male & $3(6.2 \%)$ & $2(4.1 \%)$ & $6(12.5 \%)$ & $10(2.08 \%)$ & $6(12.5 \%)$ & $7(14.5 \%)$ & $13(27 \%)$ \\
\hline
\end{tabular}

$64 \%$ of the patients visited doctors when feeling acute pain. It was enough to feel the pain for a few days. $29 \%$ of the patients asked for help from their physician after two weeks (Table 3.). Female patients turned to a doctor at least after a month, while $14 \%$ of male patients asked for help after a two weeks or a month.

Among the study subjects, the average pain threshold was 5.27. Most of them, $41 \%$ took medication only in the case of very severe pain, and $1.5 \%$ of the respondents would never take the painkiller. $47 \%$ of female patients would take a painkiller in case of a very strong pain and $22 \%$ of the men would use medication for mild pain.

\begin{tabular}{|l|c|c|c|c|}
\hline $\begin{array}{l}\text { How long does the pain last before you contact a } \\
\text { doctor? }\end{array}$ & $n$ & $\%$ & Female & Male \\
\hline 1 day - 1 week & 88 & 64 & $57(64.7 \%)$ & $31(64.5 \%)$ \\
\hline 2 weeks - 1 month & 40 & 29 & $33(37.5 \%)$ & $7(14.5 \%)$ \\
\hline - 6 months & 5 & 4 & 0 & $5(10.4 \%)$ \\
\hline More than a year & 3 & 3 & $1(1.1 \%)$ & $2(4.1 \%)$ \\
\hline Other & 0 & 0 & 0 & 0
\end{tabular}

\begin{tabular}{|l|c|c|c|c|}
\hline How often do you use a pankiller? & $\mathrm{n}$ & $\%$ & Female & Male \\
\hline Never & 12 & 9 & $6(6.8 \%)$ & $6(12.5 \%)$ \\
\hline 1/year & 39 & 29 & $22(45.8 \%)$ & $17(35.4 \%)$ \\
\hline 1/month & 46 & 34 & $32(36.3 \%)$ & $14(29.1 \%)$ \\
\hline 1/week & 24 & 18 & $17(35.4 \%)$ & $7(14.5 \%)$ \\
\hline Daily & 15 & 10 & $11(12.5 \%)$ & $4(8.3 \%)$ \\
\hline
\end{tabular}

The most common indication for self-medication with analgesics was a headache $(52 \%)$, even $56 \%$ of female respondents marked the headache as an indication. Our male subjects took painkillers mostly because of headache and articular pain (50\%). Differences in the indications of menstrual discomforts were recorded, present exclusively in female population. Migrane as indicators for
In the study $34 \%$ of the subjects used a painkiller once a month. $29 \%$ used it once a year, $18 \%$ used it once a week, $10 \%$ used it every day and $9 \%$ had never used a painkiller (Table 4.). $45 \%$ of female subjectsused an analgesic once a year and $35 \%$ used it once a week, while this ratio was lower among themale patients. self-medication was also recorded more often in female population. Sex differences in the indications for pain self-medication are shown in Table 5.

$47 \%$ of the study subjects used ibuprofen most often for pain relief, $43.1 \%$ of the female and $37.58 \%$ of the male subjects (Table 6.). Among the male respondents the next most commonly used painkiller was diclofe- 


\begin{tabular}{|c|c|c|c|c|}
\hline & $\mathrm{n}$ & $\%$ & Female & Male \\
\hline Headache & 72 & 52 & $50(56.8 \%)$ & $24(50 \%)$ \\
\hline Articular pain & 45 & 33 & $31(35.2 \%)$ & $24(50 \%)$ \\
\hline Back pain & 56 & 41 & $36(40.9 \%)$ & $12(25 \%)$ \\
\hline Menstrual discomforts & 16 & 12 & $16(18.8 \%)$ & 0 \\
\hline Sports injuries & 6 & 4 & $4(4.5 \%)$ & $2(4.1 \%)$ \\
\hline Toothache & 16 & 12 & $12(13.6 \%)$ & $2(4.1 \%)$ \\
\hline Migraine & 4 & 3 & $4(4.5 \%)$ & $1(2 \%)$ \\
\hline Abdominal pain & 7 & 5 & 7 (7.9\%) & $1(2 \%)$ \\
\hline \multirow[t]{2}{*}{ Hangover } & 3 & 2 & $1(2 \%)$ & $2(4.1 \%)$ \\
\hline & $\mathrm{n}$ & $\%$ & Female & Male \\
\hline ibuprofen & 64 & 47 & $38(43.18 \%)$ & $18(37.5 \%)$ \\
\hline diclofenac & 38 & 28 & $18(20.4 \%)$ & $14(29.1 \%)$ \\
\hline acetylsalicylic acid & 29 & 21 & $19(21.5 \%)$ & $10(20.8 \%)$ \\
\hline paracetamol & 21 & 15 & $18(20.4 \%)$ & $4(8.1 \%)$ \\
\hline $\begin{array}{l}\text { Combination of pracetamol, propyphenazone, } \\
\text { caffeine and codeine }\end{array}$ & 6 & 4 & $4(4.5 \%)$ & $2(4.1 \%)$ \\
\hline phosphate sesquihydrate (Caffetin) & 15 & 11 & $11(12.5 \%)$ & $4(8.1 \%)$ \\
\hline meloxikam & 12 & 8 & $8(9.09 \%)$ & $4(8.1 \%)$ \\
\hline metamizole & 8 & 6 & $8(9.09 \%)$ & $1(2 \%)$ \\
\hline nimesulid & 3 & 2 & $4(4.5 \%)$ & $2(4.1 \%)$ \\
\hline naproksen & 5 & 4 & $5(5.6 \%)$ & 0 \\
\hline ketoprofen & 3 & 2 & $3(3.4 \%)$ & 0 \\
\hline trospium chloride & 2 & 1 & $2(2.2 \%)$ & 0 \\
\hline
\end{tabular}

Table 5. Sex differences in the indications for pain self-medication

Table 6. Types of analgesics used by female and male subjects

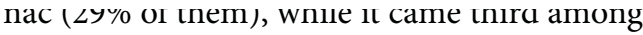
our female subjects ( $20 \%$ of them uses it). Female respondents used paracetamol more often than male respondents $(20 \%$ and $8 \%$, respectively).

$64 \%$ of patients who practised selfmedication did not ask their physician for advice, because they had heard about the medicine from their physician earlier, while $21 \%$

\begin{tabular}{|l|c|c|c|c|}
\hline & $\mathrm{n}$ & $\%$ & Female & Male \\
\hline Doctor & 87 & 64 & $60(68.1 \%)$ & $27(56.2 \%)$ \\
\hline Friend/Family member & 24 & 18 & $13(14.7 \%)$ & $11(22.9 \%)$ \\
\hline Pharmacist & 16 & 12 & $12(13.6 \%)$ & $4(8.3 \%)$ \\
\hline TV advertisement, newspaper, postere & 4 & 3 & $4(4.5 \%)$ & 0 \\
\hline Internet & 1 & 1 & 0 & $1(2.3 \%)$ \\
\hline "I've been using this medicine for years" & 29 & 21 & $16(18.1 \%)$ & $13(27 \%)$ \\
\hline
\end{tabular}

of them these medications often help, $21 \%$ of them claimed that they rarely help and $4 \%$ of them have never used any pain killers (Table 8.). The vast majority of our patients, $82 \%$, take 1-2 tablets at the same time, $86 \%$ of them are female subject, while $25 \%$ of them are men re- cramne mal mey mau usea me pankmers tor pain relief for years (Table 7.). Male respondents relied more on the advice of a friend or family member $(22 \%)$ and previous experiences $(27 \%)$, while most of the female respondents heard about the medicine from their doctors $(68 \%)$ or pharmacist $(13 \%)$.

For $38 \%$ of the study subjects these analgesics always help in pain relief, for 33\%

spondents who take more tablets. $11 \%$ of the patients often and $2 \%$ of them always take the maximum daily dose of the painkiller.

$74.2 \%$ of the subjects read the instructions for use which is in the package, $77 \%$ of them are women and $68 \%$ are men (Table
Table 7. The subjects' answer to the question: Where did you hear about this drug? 
Table 8. Characteristics of the use of painkillers

\begin{tabular}{|l|c|c|c|c|}
\hline How often is this medicine used for pain relief? & $\mathrm{n}$ & $\%$ & Female & Male \\
\hline Never & 6 & 4 & $3(3.42 \%)$ & 3 (6.2\%) \\
\hline Rarely & 30 & 21 & $18(20.4 \%)$ & $12(25 \%)$ \\
\hline Often & 47 & 33 & $33(37.5 \%)$ & $14(29.1 \%)$ \\
\hline Always & 53 & 38 & $35(39.7 \%)$ & $18(37.5 \%)$ \\
\hline What amount of painkillers are you taking? & $n$ & $\%$ & Female & Male \\
\hline 1-2 tablets at once & 112 & 82 & $76(86.3 \%)$ & $36(75 \%)$ \\
\hline $1-2$ tablets every 4 hours & 13 & 11 & $10(1.1 \%)$ & $3(6.2 \%)$ \\
\hline More than 1-2 tablets every 4 hours & 3 & 2 & $0(0 \%)$ & $3(6.2 \%)$ \\
\hline Other & 7 & 5 & $2(2.2 \%)$ & $5(10.4 \%)$ \\
\hline How often do you take the maximum allowed dose? & $n$ & $\%$ & Female & Male \\
\hline Never & 66 & 48 & $42(47.7 \%)$ & $24(50 \%)$ \\
\hline Rarely & 52 & 39 & $34(38.6 \%)$ & $18(37.5 \%)$ \\
\hline Often & 15 & 11 & $11(12.5 \%)$ & $4(8 \%)$ \\
\hline Always & 3 & 2 & $2(2.2 \%)$ & $1(2 \%)$ \\
\hline
\end{tabular}

Table 9. Knowledge about the side effects of painkillers

\begin{tabular}{|l|c|c|c|c|}
\hline Do you read the instructions? & $\mathrm{n}$ & $\%$ & Female & Male \\
\hline Yes & 101 & 74.2 & $68(\mathbf{7 7 . 2 \% )}$ & $\mathbf{3 3}(\mathbf{6 8 . 7 \% )}$ \\
\hline No & 35 & 25.8 & $20(\mathbf{2 2 . 8 \% )}$ & $\mathbf{1 5}(\mathbf{3 1 . 3 \% )}$ \\
\hline Do you know about the side effects of painkillers? & $\mathrm{n}$ & $\%$ & Female & Male \\
\hline Yes & 105 & 77.2 & $70(\mathbf{7 9 \% )}$ & $\mathbf{3 5}(\mathbf{7 2 \% )}$ \\
\hline No & 31 & 22.4 & $18(21 \%)$ & $13(28 \%)$ \\
\hline
\end{tabular}

9.). $77.2 \%$ of respondents said they knew about the side effects of drugs, but only $40 \%$ could describe those side effects. Most of our subjects have identified gastrointestinal problems such as nausea, abdominal pain, dyspepsia.
Table 10. Characteristics of the use of painkillers

\begin{tabular}{|l|c|c|c|c|}
\hline Why do not you ask the doctor for advice? & $n$ & $\%$ & Female & Male \\
\hline The pain does not last long & 65 & 48 & $41(46.5 \%)$ & $24(50 \%)$ \\
\hline The doctor is not available & 12 & 9 & $8(9 \%)$ & $4(8.3 \%)$ \\
\hline Previous experience & 44 & 32 & $34(38.6 \%)$ & $10(20.8 \%)$ \\
\hline Quick reduce & 19 & 14 & $14(29.1 \%)$ & $5(10.4 \%)$ \\
\hline Friends'/family members'recommendation & 3 & 2 & $1(1.1 \%)$ & $2(4.1 \%)$ \\
\hline Other & 10 & 7 & $6(6.8 \%)$ & $4(8.3 \%)$ \\
\hline Why do you use self-medication? & $n$ & $\%$ & Female & Male \\
\hline Saving time & 40 & 29 & $16(18.1 \%)$ & $24(50 \%)$ \\
\hline Poor pain & 57 & 42 & $41(46.5 \%)$ & $16(33.3 \%)$ \\
\hline Speed & 35 & 26 & $25(28.4 \%)$ & $10(20.8 \%)$ \\
\hline Gaining experience & 8 & 6 & $7(7.9 \%)$ & $1(20.8 \%)$ \\
\hline Easy and safe & 6 & 4 & $4(4.5 \%)$ & $2(4.1 \%)$ \\
\hline Crowd avoiding waiting & 23 & 17 & $10(11.3 \%)$ & $13(27 \%)$ \\
\hline Why are you against self-medication? & $n$ & $\%$ & Female & Male \\
\hline Risk of side effects & 61 & 45 & $40(45.4 \%)$ & $21(43.7 \%)$ \\
\hline Taking inappropriate medicine & 23 & 17 & $16(18.1 \%)$ & $7(14.5 \%)$ \\
\hline Medication not taken properly & 18 & 13 & $9(10.2 \%)$ & $7(14.5 \%)$ \\
\hline Risk of inadequate diagnosis & 14 & 10 & $9(10.2 \%)$ & $5(10.4 \%)$ \\
\hline Development of addiction & 15 & 11 & $11(12.5 \%)$ & $4(8.3 \%)$ \\
\hline Other & 5 & 5 & $2(2.2 \%)$ & $3(6.2 \%)$ \\
\hline
\end{tabular}




\begin{tabular}{|l|c|c|c|c|}
\hline & $n$ & $\%$ & Female & Male \\
\hline Not safe at all & 23 & 17 & $15(17 \%)$ & $8(16.6 \%)$ \\
\hline Partly safe & 48 & 35 & $32(36.3 \%)$ & $16(33.3 \%)$ \\
\hline Both safe and unsafe & 24 & 18 & $17(19.3 \%)$ & $7(14.5 \%)$ \\
\hline They're essentially safe & 35 & 25 & $22(25 \%)$ & $13(27 \%)$ \\
\hline They're completely safe & 4 & 3 & $1(1.1 \%)$ & $3(6.2 \%)$ \\
\hline Other & 2 & 2 & $2(2.3 \%)$ & 0
\end{tabular}

Table 11. How safe are the drugs that you can buy without prescriptions?

$66 \%$ of our subjects asked their physician/pharmacist for advice for pain relief. However, $48 \%$ did not ask for advice because the pain does not last for a long time and $32 \%$ refers to previous experiences. $42 \%$ of our patients chooses self-medication because of weak pain, $29 \%$ in order to save time and $26 \%$ to reduce the pain as fast as possible. $50 \%$ of the male subjects claimed that they use self medication to save time, $27 \%$ of them said that they want to avoid crowd and waiting in a raw. $45 \%$ of the subjects was against self-medication due to the risks of side effects. $17 \%$ thought it was dangerous to use self-medication because in that way you could take inappropriate medicine, $13 \%$ was afraid ofthe risk of taking the medicine inadequately,1 1\%was afraid of the danger of addiction, while $10 \%$ was against self-medication because of setting up the risk of inadequate diagnosis (Table 10.).

$17 \%$ of patients thought that buying drugs without a medical prescription was not safe at all. $35 \%$ of them thought it was partly safe, while $25 \%$ considered buying drugs without prescriptions to be safe (Table 11.).

The study subjects also claimed that they use other non-pharmacological options to relieve pain (Table 12.). Taking rest was the most preferred option for $73 \%$ of the patients. It was followed by drinking herb tea (46.9\%), massage $(43.8 \%)$ and applying dressing over the affected part of the body (39.3\%). The sex difference was recorded in the questions of massage, applying dressing over the affected part of the body, choosing physical activity and drinking tea for pain relief since these methods were preferred by female subjects.

\begin{tabular}{|l|c|c|c|c|}
\hline & $\mathrm{n}$ & $\%$ & Female & Male \\
\hline Rest & 100 & 73 & $66(75 \%)$ & $34(70.8 \%)$ \\
\hline Heating pad & 20 & 15 & $15(17 \%)$ & $5(10.4 \%)$ \\
\hline Massage & 40 & 29 & $31(35.2 \%)$ & $8(16.6 \%)$ \\
\hline Dressing & 23 & 17 & $18(20.4 \%)$ & $5(10.4 \%)$ \\
\hline Exercise & 19 & 14 & $15(17 \%)$ & $4(8.3 \%)$ \\
\hline Herb tea & 41 & 30 & $28(31.8 \%)$ & $8(16.6 \%)$ \\
\hline Cream & 51 & 37 & $37(42 \%)$ & $15(31.2 \%)$ \\
\hline Visiting a chiropractic & 7 & 5 & $6(6.8 \%)$ & $1(2.08 \%)$ \\
\hline Blockade & 1 & 0.7 & 0 & $1(2.08 \%)$ \\
\hline
\end{tabular}

Table 12. The most common alternative methods of pain relief

\section{DISCUSSION}

The results of the study show that self-medication with painkillers is very common among patients in the Muncipality of Bačka Topola. Taking painkillers in the past year was confirmed by $75 \%$ of the study subjects. by $85 \%$ of the women and $73 \%$ of the men. Similar results were reported in Great Britain, which show that $73 \%$ of the study subjects took painkillers in the past month [8]. Likewise, other studies also showed a higher rate of self-medication was present among female subjects
$[9,10,11]$. Similarly, in the present study, $47 \%$ of female patients would take a painkiller for a very strong pain, while $22 \%$ of the men would use medication for mild pain.

Almost $50 \%$ of the study subjects used ibuprofen most frequently, $28 \%$ of them used diclofenac and $21 \%$ of them used acetylsalicylic acid. Based on a recent study in Vojvodina, diclofenac and ibuprofen are the most commonly used painkillers [12]. This research shows that male subjects use diclofenac at a 
higher rate. The use of ibuprofen is the safest which is proved by the fact that it is the most commonly used NSAID in the European Union (Denmark, Norway, Finland) since ibuprofen is the least likely to cause gastrointestinal and cardiovascular side effects [13.14]. According to the results of this study, our male subjects used diclofenac more frequently, even though this NSAID has a detrimental effect on heart function. Therefore, in some countries of the European Union (Slovakia, Czech Republic, Hungary, Poland) the use of diclofenac was reduced. Ibuprofen was recommended instead $[15,13]$. One of the possible causes of this routine diclofenac utilization can be the more affordable price of this medicine. In Serbia, diclofenac can also be found in delayed release form (Retard), which means that you can take it once a day, while ibuprofen has been on the market in retard form only recently. This more convenient solution can also cause the frequent use of diclofenac.

Paracetamol is used by $15 \%$ of patients in the study. Paracetamol is one of the main causes of drug poisoning, while its high doses can cause adverse effects on liver function. A preventive strategy was defined in Great Britain to control the rate of paracetamol induced poisoning. For this purpose, the legislation was modified as to restrict the amount of tablets that can be bought withot prescription. With this measure. the mortality rate caused by paracetamol or acetylsalicylic acid overdose was reduced by $22 \%$, while the rate of admissions to departments of nephrology and liver transplantation because of hepatotoxic lesions which was caused by paracetamol decreased by $30 \%$ [16].

Headache was the most common indication for self-medication with painkillers, as it was claimed by $52 \%$ of the study subjects. It was followed by back pain (41\%) and articular pain $(33 \%$.). Headache has been identified as the predominant indication for medicamentous treatment in many studies [8,17-20]. A study conducted in Iran showed that $68 \%$ of patients who suffered from headache had irregular sleeping habits, changing environment Led to a stressful life and in addition, another the predictive factor of headache was poor socio-economic status [21,22]. As self-medication for pain has also been encouraged by the WHO, an appropriate approach to the user will enable safer self-medication and making correct decisions on discomfort elimination
[23]. Thus, patients will assume an active part in taking care of their health and upgrade their quality of life.

This study shows that $74.2 \%$ of the subjects $(77.2 \%$ of female and $68.7 \%$ of male subjects) reads package inserts. There were similar results in Croatia, where $76.6 \%$ of the participants in the research read the package inserts [7]. However, frequent and irregular use of drugs suggests that users are not properly informed, pointing to the need of improving the transfer of information to make selfmedication safer, more appropriate and based on good knowledge [24].

The study of patient preferences for pain self-medication conducted in the USA revealed the non-pharmacological methods of pain relief wase used by $68 \%$ of patients [25]. As many as $40 \%$ of them used exercise, $30 \%$ reported cooling/warming the body part involved, $22 \%$ used relaxation and $22 \%$ massage for pain relief. In the present study, the rate of subjects using massage for pain relief was similar (29\%), whereas data on subjects using exercise and dressings over the affected parts of the body differed considerably ( $14 \%$ and $17 \%$, respectively).

Despite analgesics being easily available to the people, they can have numerous side effects. Although $77.2 \%$ of the subjects answered "yes" to the question if they were aware of the side effects of painkillers, only $40 \%$ could describe their characteristics. Therefore it should be suggested that selfmedication of painkillers cannot be considered completely safe. These results are the key to disseminating health knowledge. At this point should be underlined that the need for advice about possible side effects of medicines should be the essential part of communication with the patients. In addition, when talking about self-medication, the pharmacist's advisory role is extremely important, as selfmedication is usually done without physician advice. Besides, since painkillers in Serbia can be purchased without a medical prescription, pharmacists are the last link to patients before analgesics use $[25,26]$.

\section{CONCLUSION}

Based on the results, self-medication and the use of painkillers are present among patients in the Municipality of Bačka Topola. However, self-medication is not without risks, 
largely due to inappropriate administration of medication.. The surveyed sample revealed many shortcomings regarding the attitudes and knowledge associated with analgesics use. Rising the level of medical knowledge and patients' awareness is an essential factor of proper self-medication. Pharmacists hold key position for monitoring the safe and effective use of painkillers through advice and counselling.

\section{ACKNOWLEDGEMENTS}

This work was supported by the Ministry of Science andTechnological Development, Republic of Serbia (project No.41012). Tinde Halgato express one's thanks to Collegium Talentum 2018 Programme for support.

\section{CONFLICTS OF INTEREST}

The authors state that they have no conflict of interest.

\section{REFERENCES}

1. Ruiz ME. Risks of Self-Medication Practices. Current Drug Safety. 2010; 5(4) 315-23.

2. Aljinović-Vučić V., Trkulja V. Lacković Z.: Content of home pharmacies and self-medication practices in households of pharmacy and medical students in Zagreb. Croatia: findings in 2001 with a reference to 1977 . CMJ 2005; 46:74-80.

3. Figueiras A., Cammano F., Gestal-Otero J.: Sociodemographic factors realted to selfmedication in Spain. Eur J Epidemiol 2000; 16:19-26.

4. Hughes CM., McElnay JC., Fleming GF.: Benefits and risks of self medication. Drug Saf 2001; 24:1027-37.

5. Dimitrijević M., Catić-Đorđević A., Stefanović N., Pavlović D., Veličković-Radovanović R.: Self-medication in primary healthcare in the territory of the city of Niš. Acta Medica Medianae 2014;53(3) 19-24.

6. Perić A., Toskić-Radojičić M.:Analysis of the use and adverse effects of non-steroidal anti-inflammatory drugs: a pilot study. Vojnosanit Pregl 2006; 63(3): 271-7.

7. Brlić KČ., Janev Holcer N., Sović S., Štimac D.: Characteristics of self-medication for pain relieg among first-year health care students in Zagreb. Croatia. Psychiatria Danubina. 2014; 26(3) 459-65.

8. French DP., James DH.: Reasons for the use of mild analgetics among English students. Pharm World Sci 2008; 30:79-85.

9. Bassols A., Bosch F., Banos JE.: How does the general population treat their pain? A survery in Catalo- nia. Spain. J Pain Syptom Manage 2002; 23:318-28.

10. James H., Handu SS., Al Khaja KAJ., Sequeira RP.: Infuence of medical training on self-medication by students. Int J Clin Pharmacol Ther 2008; 46:239.

11. Klemenc-Ketiš Z., Hladnik Ž., Kersnik J.: A cross sectional study of sex differences in self-medication practices among university students in Slovenia. Coll Antropol 2011; 35:329-34.

12. Horvat O., Mijatović V., Ćalasan. J., Sabo A.: Outpatient utilization of non-steroidal anti-inflammatory drugs in three largest municipalities in South Bačka District. Srpski arhiv za celokupno lekarstvo. 2012;140(5-6):339-43.

13. Danish Medicines Agency. Medicinal Products Statistics in Denmark 20042008. Sales within the different ATC groups. primary healthcare sector. Available from: http://www.dkma.dk/db/filarkiv/6692/Kapitel2.pdf.

14. Hudec R., Kriska M., Bozekova L., Foltan V. Comparison of NSAID consumption in Slovakia. Finland and Norway. Bratis Lek Listy.2008; 109(8):3703.

15. Inotai A., Hankó B., Mészáros A. Trends in the nonsteroidal antiinflammatory drug market in six CentralEastern European countries based on retail information. Pharmacoepidemiol Drug Saf. 2010; 19(2):18390.

16. Hawton K., Simkin S., Deeks J., Cooper J., Johnston A., Waters K. et al.: UK legislation on analgesic packs: before and after study of long term effects on poisonings. BMJ 2004; 329:1076-80.

17. Burak LJ., Damico A.: College students use of widely advertised medications. J Am Coll Health 2000; 49:118-21.

18. Gutema BG., Gadisa AD., Kidanemariam AZ., Berhe FD., Berhe HA., Hadera GM. et al.: Self-Medication Practices among Health Sciences Students: The Case of Mekelle University. JAPS 2011; 10:18389.

19. Souza LAF., Da Silva CD., Ferraz GC., Sousa FAE., Pereira LV.: The prevalence and characterization of self-medication for obtaining pain relief among undergrade nursing students. Rev. Latino-AM. Enfermagem 2011; 19:245-51.

20. James H., Handu SH., Al Khaja KAJ., Otoom S., Sequeira RP.: Evaluation of the knowledge. attidude and practice of self-medication among first-year medical students. Med Princ Pract 2006; 15:270-75.

21. Menon B., Kinnera N.: Prevalence and characteristics of migraine in medical students and its impact on their daily activities. Ann Indian Acad Neurol 2013; 16:221-25.

22. Ghorbani A., Abtahi SM., Fereidan-Esfahani M., Abtahi SH., Shemshaki H., Akbari M. et al.: Prevalence and clinical characteristics of headache 
among medical students. Isfahan. Iran. J Res Med Sci 2013; 18:24-7.

23. World Health Organization: Guidelines for the Regulatory Assessment of Medicinal Products for Use in Self-Medication. World Health Organization. 2002. http://apps.who.int/medicinedocs/en/d/ Js2218e/

24. Sanz F., Gaedt K., Alonso A., Díaz C.: New technologies for the marketing and sale of medicines on the internet and television networks. European Parliament: The STOA Programme: EP/IV/B/ STOA $/ 99 / 07 / 01.2000$.

25. Jakševac Mikša M.: Role of the pharmacist in Pharmacotherapy counselling. Medicus 2002; 11:138.

26. Vallerand AH., Fouladbakhsh J., Templin T.: Patients' choices for the self-treatment of pain. ANR 2005; 18:90-6. 


\section{Samomedikacija pacijenata analgeticima u opštini Bačka Topola}

Tinde I. Halgato ${ }^{1}$, Ana D. Tomas², Milica M. Paut Kusturica ${ }^{2}$, Olga J. Horvat ${ }^{2}$

${ }^{1}$ Dom zdravlja “ Dr Janoš Hadži” Bačka Topola, Srbija

${ }^{2}$ Katedra za farmakologiju, toksikologiju i kliničku farmakologiju, Medicinski fakultet Novi Sad,

Univerzitet u Novom Sadu, Novi Sad, Srbija

\section{KRATAK SADRŽAJ}

Uvod: U Srbiji analgetici su dostupni bez lekarskog recepata, pa pacijenti sve češće koriste lekove za smanjenje bolova bez konsultacije lekara.

Cilj: Svrha ovog rada je da se utvrde stavovi pacijenata o samomedikaciji analgeticima i karakteristike same samomedikacije među pacijentima u Opštini Bačka Topola. Metodologija: Istraživanje je sprovedeno u periodu od 20-29.09.2017. u tri ambulante Doma zdravlja u opštini Bačka Topola. Ukupno 136 pacijenata, koji su popunili anketni upitnik, je učestvovalo u ispitivanje.

Rezultati: 75\% ispitanika je koristilo analgetik u toku prethodne godine, a 34\% jednom mesečno. Najčešće indikacije bile su: glavabolja $52 \%$, bolovi u zglobovima $33 \%$ i bolovi u krstima $41 \%$. Najčešće su korišćeni ibuprofen $47 \%$, diklofenak $28 \%$ i acetilsalicilna kiselina $21 \%$. Čak $48 \%$ ispitanika je izjavilo da je koristilo analgetike bez prethodne konsultacije lekara (samomedikacija), jer bol nije bio dovoljno jak i nije trajao dugo, a na osnovu prethodnog iskustva analgetike je koristilo njih $32 \%$. Pacijenti nisu posetili lekara jer je bol nije bio jak u $42 \%$ slučajeva, a zbog ušteda vremena u $29 \%$. $77 \%$ ispitanika je tvrdilo da je upoznato sa neželjenim dejstvima analgetika, ali samo 40\% njih ih je znalo nabrojati.

Zaključak: Rezultati našeg istraživanja ukazuju da znanje pacijenata o analgeticima ima veoma važnu ulogu u njihovoj racionalnoj primeni. Stoga su edukativne kampanje o ponašanju pacijenata prema analgeticima ključni elementi kvalitetne i svesne medikacija koja se temelji na znanju.

Ključne reči: nesterodni antiinflamatorni lekovi, neželjena dejstva, neracionalna upotreba lekova 